\title{
Advances in the treatment of mitochondrial epilepsies
}

Professor Shamima Rahman

UCL Great Ormond Street Institute of Child Health, London, UK

Address for correspondence:

Professor Shamima Rahman

Mitochondrial Research Group,

UCL Great Ormond Street Institute of Child Health,

London, United Kingdom

Phone: $+44(0) 2079052608$

Fax: +44 (0)2074046191

E-mail: shamima.rahman@ucl.ac.uk

\section{Key words}

Mitochondrial disease; Clinical trials; Antioxidants; Mitochondrial biogenesis; Rapamycin; Gene therapy 


\begin{abstract}
Epilepsy is frequently a severe and sinister symptom in primary mitochondrial diseases, a group of more than 350 different genetic disorders characterised by mitochondrial dysfunction and extreme clinical and biochemical heterogeneity. Mitochondrial epilepsy is notoriously difficult to manage, principally because the vast majority of primary mitochondrial diseases currently lack effective therapies. Treating the underlying mitochondrial disorder is likely to be a more effective strategy than using traditional antiepileptic drugs. This review, initially presented at the $7^{\text {th }}$ London-Innsbruck Colloquium on Status Epilepticus and Acute Seizures at the Francis Crick Institute in London, summarises the currently available and emerging therapies for mitochondrial epilepsy. Potentially treatable mitochondrial diseases include disorders of coenzyme $Q_{10}$ biosynthesis and a group of mitochondrial respiratory chain complex I subunit and assembly factor defects that respond to riboflavin (vitamin B2). Approaches that have been adopted in actively recruiting clinical trials include redox modulation, harnessing mitochondrial biogenesis, using rapamycin to target mitophagy, nucleoside supplementation, and gene and cell therapies. Most of the clinical trials are at an early stage (Phase 1 or 2 ) and none of the currently active trials is specifically targeting mitochondrial epilepsy.
\end{abstract}




\section{Introduction}

Primary mitochondrial diseases have recently been redefined as disorders caused by mutations that "primarily or secondarily lead to oxidative phosphorylation (OXPHOS) dysfunction or other disturbances of mitochondrial structure and function including perturbed mitochondrial ultrastructure, aberrant synthesis of cofactors and vitamins, or other impaired metabolic processes within the mitochondrion" [1]. Epilepsy is reported to affect up to $40 \%$ of patients with primary mitochondrial disease [2] and is often a late and sinister clinical feature; $50 \%$ of affected patients died within 9 months after seizure onset in one cohort [3]. Unfortunately there are currently no effective therapies for the vast majority of mitochondrial diseases, and this includes the mitochondrial epilepsies. This brief review, originally presented on 9 April 2019 at the $7^{\text {th }}$ London-Innsbruck Colloquium on Status Epilepticus and Acute Seizures at the Francis Crick Institute in London, summarises the currently available treatments for mitochondrial epilepsy and emerging therapies either undergoing clinical trial or on the horizon.

\section{Antiepileptic drugs and supportive management}

Many mitochondrial epilepsies are notoriously resistant to antiepileptic drugs (AEDs), and patients have been reported to be resistant to many different combinations of drugs. There continue to be anecdotal case reports and small case series reporting benefit of specific AEDs in patients with mitochondrial epilepsies (e.g. [4, 5]), but the clinical, biochemical and genetic heterogeneity of mitochondrial epilepsies, and the unpredictable natural course, makes interpretation of such reports extremely challenging. In an ideal world the primary treatment should clearly be directed at the underlying cause rather than waiting to treat seizures when they occur. However at present there are no disease-modifying therapies for the vast majority of mitochondrial diseases, and supportive treatments remain the principal therapies offered to affected patients. These include AEDs and treatment of multisystemic disease complications when they occur [6].

\section{Cofactor and vitamin responsive disorders}

There are some notable exceptions of primary mitochondrial disorders where disease-modifying therapies do exist, and it is important to recognise these disorders promptly. The most well-known subgroup comprises disorders of coenzyme $\mathrm{Q}_{10}$ (ubiquinone) biosynthesis, which at least in theory are likely to be ameliorated by supplementation with pharmacological doses of coenzyme $Q_{10}$ [7]. Coenzyme $Q_{10}$ functions as a mobile electron carrier within the respiratory chain, as well as being a potent antioxidant. Coenzyme $\mathrm{Q}_{10}$ at $30 \mathrm{mg} / \mathrm{kg} /$ day was reported to prevent renal impairment in a child with COQ2 mutations whose sibling had end-stage renal failure, seizures, stroke-like episodes and cognitive impairment [8]. However a more recent 
report described progressive neurological dysfunction, including seizures and encephalopathy, in patients with COQ2 deficiency whose initial symptoms of diabetes and nephrotic syndrome had responded to coenzyme $Q_{10}$ supplementation in the neonatal period [9]. Progression of neurological disease may be because of limited intracerebral bioavailability of coenzyme $Q_{10}$. Another issue is that other coenzyme $Q_{10}$ biosynthesis defects, particularly $\mathrm{COQ}_{4}$ and $\mathrm{COQ} 9$ mutations, appear to have prenatal onset and are associated with severe disease progression and early death, despite prompt initiation of coenzyme $Q_{10}$ supplementation [10-13], so other treatment strategies may be needed for this group of disorders.

Another group of potentially treatable mitochondrial disorders are those that respond to supplementation with riboflavin (vitamin B2) [14]. These include some complex I deficiencies, particularly mutations of ACAD9, encoding a flavoprotein required for complex I assembly. Affected patients typically have a good clinical response to riboflavin supplementation [15]. The most frequent clinical features associated with ACAD9 deficiency are hypertrophic cardiomyopathy, lactic acidosis and exercise intolerance, but seizures have been reported in occasional cases $[16,17]$. Mutations of AIFM1, encoding apoptosis inducing factor mitochondria associated 1, another flavoprotein required for complex I assembly, have been reported to cause riboflavinresponsive ataxia in two patients [18]. AIFM1 mutations have also been associated with seizures, but riboflavin therapy was not reported in these individuals [19]. Riboflavin may also be beneficial in other complex I deficiencies, particularly mutations of the NDUFV1 and NDUFV2 subunits which are flavoproteins interacting with the flavin mononucleotide (FMN) active cofactor of the complex I holoenzyme [14].

The role of vitamins and cofactors in other mitochondrial disorders is uncertain. There have been very few randomised clinical trials in primary mitochondrial diseases, and a Cochrane review published in 2012 concluded that further research is needed in this area [20].

\section{Development of novel therapies}

Development of novel therapies for mitochondrial disease is a growth industry. However, despite more than 2000 publications per year on mitochondrial disease treatment there are currently no licensed treatments for systemic mitochondrial disease. Why is it so difficult to treat mitochondrial disease? The multi-layered complexity of mitochondrial disease, with extreme clinical, biochemical and genetic heterogeneity, provides an enormous barrier to therapy development. However, despite these difficulties, a large number of candidate therapies is currently in development $[1,21]$.

Novel therapies in development for mitochondrial disease may be divided broadly into two groups: pharmacological and genetic treatments. Many of the pharmacological approaches are generic 'disease 
agnostic' approaches and include targeting reactive oxygen species, stabilising the mitochondrial membrane, harnessing mitochondrial biogenesis and targeting mitophagy (Figure 1).

\section{Antoxidant approaches}

Antioxidants have played a central role in the (attempted) treatment of mitochondrial disease for decades, although evidence for their efficacy remains limited at present [20]. The central tenet underlying their use is that impairment of mitochondrial function, especially of complexes I and III, leads to excessive generation of reactive oxygen species (ROS), which in turn leads to a vicious cycle of further mitochondrial damage, including lipid, protein and DNA peroxidation. ROS include the superoxide radical and hydrogen peroxide. Accumulating evidence implicating ROS in seizure generation outside the context of primary mitochondrial disease $[22,23]$ supports the continuing use of antioxidants in mitochondrial epilepsies, in the absence of more specific disease-modifying therapies. A word of caution is that ROS are not merely damage-inducing molecules but rather have important physiological roles in the mitochondrion and in the cell, especially in inter-organellar signalling [24]. One study suggested that excessive antioxidant exposure could be harmful in a mouse model of mitochondrial disease; a muscle-specific COX15 knockout had worse survival following $\mathrm{N}$-acetylcysteine (NAC) therapy [25]. The antioxidants used in clinical practice include coenzyme $Q_{10}, N A C$ and vitamins $E$ and C. Newer antioxidants that have been investigated in preclinical studies include EPI-743 and KH176. Open label studies of EPI-743 in the mitochondrial encephalomyelopathy Leigh syndrome did not conclusively demonstrate benefit $[26,27]$. The KHENERGY study, a double-blind, randomized, placebo-controlled, two-way crossover phase IIA study of KH176, demonstrated tolerability and safety in adult patients with relatively mild multisystemic disease related to the m.3243A>G mutation (average heteroplasmy $61 \%$ in urinary epithelial cells, $18 \%$ in leukocytes) [28]. A phase III study is planned but not yet active.

\section{Harnessing mitochondrial biogenesis}

The process of making new mitochondria, known as mitochondrial biogenesis, is ultimately regulated by the master transcriptional co-activator PGC1 $\alpha$, which interacts with multiple transcription factors including the nuclear respiratory factors NRF1 and NRF2 and the peroxisome proliferator-activated receptors (PPARs), leading to increased transcription of hundreds of genes encoding mitochondrial components including OXPHOS subunits and assembly factors and fatty acid oxidation enzymes [29]. Theoretically, increasing mitochondrial mass by stimulating mitochondrial biogenesis should result in a net increase in energy production and thus potentially ameliorate at least some of the effects of mitochondrial dysfunction. Several therapeutic approaches have attempted to manipulate this process by activating PGC1 $\alpha$ by modulating its 
acetylation (e.g. by activating the SIRT1 deacetylase) or phosphorylation (e.g. via the AMP-activated protein kinase) or by increasing PGC1 $\alpha$ target molecules such as the PPARs (e.g. with decanoic acid). As with antioxidant therapies, evidence for efficacy of these approaches is currently limited. Initial studies of bezafibrate, resveratrol and AICAR in animal models yielded conflicting data [30]. A clinical trial of resveratrol in mitochondrial myopathies is ongoing (NCT03728777, Table 1) and a trial of bezafibrate has recently completed but is yet to report its results (NCT02398201, clinicaltrials.gov). We observed promising preclinical data in human patient cell models of complex I deficiency treated with decanoic acid (C10) [31], but this has not yet been translated into a clinical trial for primary mitochondrial disease. Increasing NAD+, either by supplementing with the vitamin B3 derivative nicotinamide riboside or by inhibiting poly(ADP-ribose) polymerase 1 (PARP1, which consumes $\mathrm{NAD+}$ ), may also promote mitochondrial biogenesis by activating SIRT1. Increasing NAD ${ }^{+}$availability ameliorated the phenotypes of two mouse models of mitochondrial disease $[32,33]$, and improved mitochondrial function in human complex I deficient fibroblasts [34]. Two actively recruiting trials are investigating an NAD+ modulator KL 1333 (NCT03888716) and nicotinamide riboside (NCT03432871) whilst a third aims to use a novel PPAR agonist REN001 (NCT03862846) to increase mitochondrial biogenesis (Table 1). It is interesting to note that all of the active trials investigating mitochondrial biogenesis as a therapeutic strategy are targeting mitochondrial myopathies; none are aiming to treat mitochondrial epilepsies, possibly because of the challenges inherent in targeting molecules to the central nervous system.

\section{Targeting mitophagy}

Inhibition of the mTOR pathway by rapamycin has been used to target mitophagy, the process of selective elimination of dysfunctional mitochondria. Several recent preclinical studies have reported beneficial effects of rapamycin in treating mitochondrial disease; high-dose intraperitoneal rapamycin increased survival and attenuated the neurological phenotype and brain lesions of Ndufs4-/- mice, a murine model of Leigh syndrome, and also improved the phenotype of myopathic 'deletor' mice harbouring a mutation in the twinkle DNA helicase, whilst low dose rapamycin increased survival of Tk2 deficient mice [35-37]. In contrast, there was no evidence of benefit from rapamycin in an encephalomyopathic mouse model harbouring a homozygous nonsense mutation in the coenzyme $Q_{10}$ biosynthetic factor Coq9 [38]. Switching immunosuppression from calcineurin inhibitors to mTOR inhibitors was reported to lead to clinical improvement in four renal transplant patients with mitochondrial disease related to the m.3243A>G mutation (associated with mitochondrial encephalomyopathy with lactic acidosis and stroke-like episodes, MELAS) [39]. Recently investigators in New York treated two patients with mitochondrial seizures with everolimus, a rapamycin analogue. The authors reported apparent benefit of everolimus in the first child, who had Leigh 
syndrome caused by a homozygous NDUFS4 mutation, but the second child, who had m.3243A>G MELAS, had progressive disease despite everolimus therapy and subsequently died [40]. The mechanisms underlying the potential efficacy of rapamycin in mitochondrial disease remain unknown. Modulation of mitophagy is the most favoured mechanism but other possibilities include increased lysosomal biogenesis and metabolic reprogramming to reduce the dependence on OXPHOS [40]. The mTOR pathway has also been linked to folate availability, which is interesting since folate is a key player in one-carbon metabolism, a metabolic pathway implicated in the pathogenesis of mitochondrial disease $[36,41,42]$. The variable findings of the preclinical and compassionate use data suggest that rapamycin may not be a universal panacea for mitochondrial disease. A formal clinical trial is needed to determine which patients may benefit from rapamycin or everolimus and to establish the lowest efficacious dose, in view of the known adverse effects associated with these drugs, including immunosuppression and hyperlipidaemia. A clinical trial of NAB-sirolimus (nanoparticle albumin-bound rapamycin) in genetically confirmed Leigh syndrome is currently active although not yet recruiting patients (NCT03747328, Table 1).

Hypoxia

A genome-wide CRISPR screen identified the Von Hippel Lindau (VHL) ubiquitin ligase as a key factor rescuing mitochondrial dysfunction in a cellular model, thus implicating the hypoxia inducible factor (HIF) transcriptional pathway as a therapeutic target in mitochondrial disease [43]. The authors went on to demonstrate that maintaining the Ndufs4-/- Leigh syndrome mice in chronic hypoxic conditions $\left(\begin{array}{lll}11 \% & \mathrm{O}_{2}\end{array}\right)$ prolonged survival and attenuated the brain lesions observed in these mutant mice [43]. A more recent study by the same group has shown that the mechanism of neuroprotection by hypoxia in the Ndufs4-/- mouse is by prevention of brain tissue hyperoxia rather than by activation of the HIF pathway [44]. Chronic hypoxia is obviously not a therapy of choice for human patients, so clinical translation of this treatment will be challenging. However, an immediate clinical message is that hyperoxia should be avoided in mitochondrial patients in the intensive care unit $[45,46]$, including those with mitochondrial status epilepticus.

\section{Other pharmacological approaches}

Another pharmacological approach is to stabilise the inner mitochondrial membrane lipid milieu in which the OXPHOS complexes and supercomplexes are embedded, in order to preserve mitochondrial function. Elamipretide (SS-31, MTP-131) is a Szeto-Schiller tetrapeptide (D-Arg-dimethylTyr-Lys-Phe-NH2) that appears to stabilise cardiolipin, the major lipid component of the inner mitochondrial membrane. A recently completed clinical trial of elamipretide in adults with primary mitochondrial myopathy, the MMPOWER study, reported 
improvements in the 6 minute walk test after 5 days of treatment [47]. A phase 3 double-blind placebocontrolled trial of elamipretide in mitochondrial myopathy is due to start recruiting patients shortly (NCT03323749, Table 1). Intriguingly, the small molecule nature of elamipretide means that it is able to cross the blood brain barrier (BBB) [48], which makes it potentially a relevant molecule to treat mitochondrial epilepsies.

Stroke-like episodes (SLES) are increasingly recognised to represent seizure activity. Management of the canonical mitochondrial stroke syndrome MELAS is extremely challenging [49]. Agents which have aimed to address SLEs in MELAS include L-arginine, L-citrulline, L-taurine and succinate, but high level evidence of efficacy is currently lacking. Nitric oxide deficiency has been implicated in the pathogenesis of SLEs and there was apparent benefit of the nitric oxide precursor L-arginine in both prevention and amelioration of SLEs in a series of open-label studies performed in Japan $[50,51]$. As a consequence of these open-label studies, Larginine use in MELAS has become widespread across the globe even though a randomised placebo-controlled trial has never been performed. A dose-finding study of L-citrulline, another precursor of nitric oxide, in MELAS is currently in progress (NCT03952234, Table 1).

Nucleosides have shown efficacy in preclinical trials to treat myopathic mitochondrial DNA depletion syndrome (MDDS) caused by thymidine kinase 2 (TK2) deficiency [52], and a compassionate use study recently reported beneficial effects in affected children and adults [53]. A Phase 2 open label extension of combination pyrimidine nucleosides in TK2 deficiency is ongoing (NCT03845712). The ability of nucleosides to penetrate the BBB is not known, and whether these molecules would successfully treat seizures in encephalomyopathic forms of MDDS remains controversial.

\section{Genetic and cellular therapies}

Genetic therapies need to target the mtDNA or nuclear genome, depending on the specific mitochondrial disorder. Adeno-associated viral (AAV) vector mediated gene therapy has been reported in several preclinical models of nuclear-encoded mitochondrial disease, including mouse models of mitochondrial neurogastrointestinal encephalomyopathy (MNGIE) and ETHE1, MPV17 and NDUFS4 deficiencies [54-57]. These have shown generally positive effects and could potentially be a useful therapeutic strategy for all nuclear-encoded mitochondrial diseases. However, the limiting factor at present is the enormous expense and time requirement to develop and treat preclinical models for $>300$ different gene defects. Unless new methods are developed to scale up these treatments, or regulatory agencies relax the preclinical therapy requirements in some way, it is unrealistic to expect that gene therapy will ever be available for the large number of ultrarare mitochondrial gene defects affecting only a few individuals each worldwide. CRISPR-based gene editing 
was used to rescue mitochondrial dysfunction in an induced pluripotent stem cell model of coenzyme $Q_{10}$ deficiency [58], and this may be another therapeutic strategy for nuclear-encoded mitochondrial diseases going forwards.

Targeting the mitochondrial genome is more challenging, since it is relatively inaccessible owing to its protected position within the mitochondrion, encased by two lipid membranes. However, recent approaches using mitochondrial TALENs and zinc finger nucleases to target and selectively eliminate mutant mtDNA sequences have shown benefit in both cell and animal models of heteroplasmic mtDNA disease [59-62]. A concern is that selective destruction of mutant mtDNA at high heteroplasmy level may lead to a temporary state of mtDNA depletion before the wild-type mtDNA recovers to normal copy numbers, and patients would be extremely vulnerable during this recovery period. Strategies to tackle this problem are awaited, but it is theoretically possible that nucleoside supplementation may hasten the recovery of the wild-type mtDNA in this situation.

Another gene therapy approach, currently in clinical trial, is to treat LHON by intra-ocular injection of AAV2ND4 recoded in the nuclear genetic code so that it can be expressed from the nucleus, the recombinant protein being synthesised on cytosolic ribosomes and subsequently imported into the mitochondrion (NCT02161380, Table 1) [63]. How this could be adapted for treatment of mitochondrial epilepsies, which would need at least systemic gene therapy if not intrathecal or intra-cerebroventricular injection, remains to be determined.

Organ transplantation as a genetic rescue for mitochondrial disease has been explored for MNGIE using either allogeneic haematopoietic stem cell transplantation (AHSCT - NCT02427178, Table 1) or liver transplantation, and for ETHE1 deficiency (liver transplantation) [64-66]. A trial of erythrocyte-encapsulated thymidine phosphorylase enzyme replacement therapy in MNGIE is about to start recruiting patients (NCT03866954, Table 1) [67]. Another study is examining the effects of transplantation of autologous CD34+ haematopoietic stem cells enriched with maternal blood-derived mitochondria (MNV-BLD) in children with the Pearson marrow pancreas syndrome (NCT03384420).

\section{Concluding remarks}

Recent years have seen a dramatic increase in the number of novel therapies under development for primary mitochondrial disease. At the time of writing (24 August 2019) a search for 'mitochondrial diseases' identified 215 trials in clinicaltrials.gov, of which at least 8 are interventional studies actively recruiting patients (Table 1). Although none of the active trials are specifically targeting mitochondrial epilepsy, this is an exciting time for mitochondrial disease, and the possibility of effective therapies for these devastating disorders is finally on the horizon. 


\section{Acknowledgements}

The author's research group is funded by Great Ormond Street Hospital Children's Charity, the NIHR Great Ormond Street Hospital Biomedical Research Centre, Action Medical Research and the Lily Foundation. The author thanks Dr Elaina Maldonado for assistance with the artwork.

\section{References}

[1] Rahman J, Rahman S. Mitochondrial medicine in the omics era. Lancet 2018;391: 2560-2574.

[2] Rahman S. Pathophysiology of mitochondrial disease causing epilepsy and status epilepticus. Epilepsy Behav 2015;49: 71-5.

[3] El Sabbagh S, Lebre AS, Bahi-Buisson N, Delonlay P, Soufflet C, Boddaert N, Rio M, Rotig A, Dulac O, Munnich A, Desguerre I. Epileptic phenotypes in children with respiratory chain disorders. Epilepsia 2010;51: 1225-35.

[4] Primiano G, Vollono C, Dono F, Servidei S. Drug-resistant epilepsy in MELAS: safety and potential efficacy of lacosamide. Epilepsy Res 2018;139: 135-136.

[5] Santamarina E, Alpuente A, Maisterra O, Sueiras M, Sarria S, Guzman L, Abraira L, Salas-Puig J, Toledo M. Perampanel: A therapeutic alternative in refractory status epilepticus associated with MELAS syndrome. Epilepsy Behav Case Rep 2019;11: 92-95.

[6] Rahman S. Emerging aspects of treatment in mitochondrial disorders. J.Inherit.Metab Dis. 2015;38: 641-653.

[7] Rahman S, Clarke CF, Hirano M. 176th ENMC International Workshop: Diagnosis and treatment of coenzyme Q(10) deficiency. Neuromuscul.Disord. 2012;22: 76-86.

[8] Montini G, Malaventura C, Salviati L. Early coenzyme Q10 supplementation in primary coenzyme Q10 deficiency. N.Engl.J.Med. 2008;358: 2849-2850.

[9] Eroglu FK, Ozaltin F, Gonc N, Nalcacioglu H, Ozcakar ZB, Yalnizoglu D, Gucer S, Orhan D, Eminoglu FT, Gocmen R, Alikasifoglu A, Topaloglu R, Duzova A. Response to Early Coenzyme Q10 Supplementation Is not Sustained in CoQ10 Deficiency Caused by CoQ2 Mutation. Pediatr Neurol 2018;88: 71-74.

[10] Brea-Calvo G, Haack TB, Karall D, Ohtake A, Invernizzi F, Carrozzo R, Kremer L, Dusi S, Fauth C, SchollBurgi S, Graf E, Ahting U, Resta N, Laforgia N, Verrigni D, Okazaki Y, Kohda M, Martinelli D, Freisinger P, Strom TM, Meitinger T, Lamperti C, Lacson A, Navas P, Mayr JA, Bertini E, Murayama K, Zeviani M, Prokisch H, Ghezzi D. COQ4 mutations cause a broad spectrum of mitochondrial disorders associated with CoQ10 deficiency. Am.J.Hum.Genet. 2015;96: 309-317.

[11] Rahman S, Hargreaves I, Clayton P, Heales S. Neonatal presentation of coenzyme Q10 deficiency. J.Pediatr. 2001;139: 456-458.

[12] Duncan AJ, Bitner-Glindzicz M, Meunier B, Costello H, Hargreaves IP, Lopez LC, Hirano M, Quinzii CM, Sadowski MI, Hardy J, Singleton A, Clayton PT, Rahman S. A nonsense mutation in COQ9 causes autosomalrecessive neonatal-onset primary coenzyme Q10 deficiency: a potentially treatable form of mitochondrial disease. Am.J.Hum.Genet. 2009;84: 558-566.

[13] Smith AC, Ito Y, Ahmed A, Schwartzentruber JA, Beaulieu CL, Aberg E, Majewski J, Bulman DE, HorstingWethly K, Koning DV, Rodenburg RJ, Boycott KM, Penney LS. A family segregating lethal neonatal coenzyme Q10 deficiency caused by mutations in COQ9. J Inherit Metab Dis 2018;41: 719-729.

[14] Balasubramaniam S, Christodoulou J, Rahman S. Disorders of riboflavin metabolism. J Inherit Metab Dis 2019.

[15] Repp BM, Mastantuono E, Alston CL, Schiff M, Haack TB, Rotig A, Ardissone A, Lombes A, Catarino CB, Diodato D, Schottmann G, Poulton J, Burlina A, Jonckheere A, Munnich A, Rolinski B, Ghezzi D, Rokicki D, 
Wellesley D, Martinelli D, Wenhong D, Lamantea E, Ostergaard E, Pronicka E, Pierre G, Smeets HJM, Wittig I, Scurr I, de Coo IFM, Moroni I, Smet J, Mayr JA, Dai L, de Meirleir L, Schuelke M, Zeviani M, Morscher RJ, McFarland R, Seneca S, Klopstock T, Meitinger T, Wieland T, Strom TM, Herberg U, Ahting U, Sperl W, Nassogne MC, Ling H, Fang F, Freisinger P, Van Coster R, Strecker V, Taylor RW, Haberle J, Vockley J, Prokisch H, Wortmann S. Clinical, biochemical and genetic spectrum of 70 patients with ACAD9 deficiency: is riboflavin supplementation effective? Orphanet J Rare Dis 2018;13: 120.

[16] Collet M, Assouline Z, Bonnet D, Rio M, Iserin F, Sidi D, Goldenberg A, Lardennois C, Metodiev MD, Haberberger B, Haack T, Munnich A, Prokisch H, Rotig A. High incidence and variable clinical outcome of cardiac hypertrophy due to ACAD9 mutations in childhood. Eur J Hum Genet 2016;24: 1112-6.

[17] Aintablian HK, Narayanan V, Belnap N, Ramsey K, Grebe TA. An atypical presentation of ACAD9 deficiency: Diagnosis by whole exome sequencing broadens the phenotypic spectrum and alters treatment approach. Mol Genet Metab Rep 2017;10: 38-44.

[18] Heimer G, Eyal E, Zhu X, Ruzzo EK, Marek-Yagel D, Sagiv D, Anikster Y, Reznik-Wolf H, Pras E, Oz Levi D, Lancet D, Ben-Zeev B, Nissenkorn A. Mutations in AIFM1 cause an X-linked childhood cerebellar ataxia partially responsive to riboflavin. Eur J Paediatr Neurol 2018;22: 93-101.

[19] Kettwig M, Schubach M, Zimmermann FA, Klinge L, Mayr JA, Biskup S, Sperl W, Gartner J, Huppke P. From ventriculomegaly to severe muscular atrophy: expansion of the clinical spectrum related to mutations in AIFM1. Mitochondrion 2015;21: 12-8.

[20] Pfeffer G, Majamaa K, Turnbull DM, Thorburn D, Chinnery PF. Treatment for mitochondrial disorders. Cochrane.Database.Syst.Rev. 2012;4: CD004426.

[21] Hirano M, Emmanuele V, Quinzii CM. Emerging therapies for mitochondrial diseases. Essays Biochem 2018;62: 467-481.

[22] Shekh-Ahmad T, Kovac S, Abramov AY, Walker MC. Reactive oxygen species in status epilepticus. Epilepsy Behav 2019: 106410.

[23] Shekh-Ahmad T, Lieb A, Kovac S, Gola L, Christian Wigley W, Abramov AY, Walker MC. Combination antioxidant therapy prevents epileptogenesis and modifies chronic epilepsy. Redox Biol 2019;26: 101278.

[24] Sena LA, Chandel NS. Physiological roles of mitochondrial reactive oxygen species. Mol Cell 2012;48: 158-67.

[25] Dogan SA, Cerutti R, Beninca C, Brea-Calvo G, Jacobs HT, Zeviani M, Szibor M, Viscomi C. Perturbed Redox Signaling Exacerbates a Mitochondrial Myopathy. Cell Metab 2018;28: 764-775.e5.

[26] Enns GM, Kinsman SL, Perlman SL, Spicer KM, Abdenur JE, Cohen BH, Amagata A, Barnes A, Kheifets $V$, Shrader WD, Thoolen M, Blankenberg F, Miller G. Initial experience in the treatment of inherited mitochondrial disease with EPI-743. Mol.Genet.Metab 2012;105: 91-102.

[27] Martinelli D, Catteruccia M, Piemonte F, Pastore A, Tozzi G, Dionisi-Vici C, Pontrelli G, Corsetti T, Livadiotti S, Kheifets V, Hinman A, Shrader WD, Thoolen M, Klein MB, Bertini E, Miller G. EPI-743 reverses the progression of the pediatric mitochondrial disease--genetically defined Leigh Syndrome. Mol.Genet.Metab 2012;107: 383-388.

[28] Janssen $M C H$, Koene $S$, de Laat $P$, Hemelaar P, Pickkers $P$, Spaans E, Beukema R, Beyrath J, Groothuis J, Verhaak C, Smeitink J. The KHENERGY Study: Safety and Efficacy of KH176 in Mitochondrial m.3243A>G Spectrum Disorders. Clin Pharmacol Ther 2019;105: 101-111.

[29] Spiegelman BM. Transcriptional control of mitochondrial energy metabolism through the PGC1 coactivators. Novartis Found Symp 2007;287: 60-3; discussion 63-9.

[30] Kanabus M, Heales SJ, Rahman S. Development of pharmacological strategies for mitochondrial disorders. Br.J.Pharmacol. 2014;171: 1798-1817.

[31] Kanabus M, Fassone E, Hughes SD, Bilooei SF, Rutherford T, Donnell MO, Heales SJ, Rahman S. The pleiotropic effects of decanoic acid treatment on mitochondrial function in fibroblasts from patients with complex I deficient Leigh syndrome. J Inherit Metab Dis 2016;39: 415-26.

[32] Khan NA, Auranen M, Paetau I, Pirinen E, Euro L, Forsstrom S, Pasila L, Velagapudi V, Carroll CJ, Auwerx J, Suomalainen A. Effective treatment of mitochondrial myopathy by nicotinamide riboside, a vitamin B3. EMBO Mol.Med. 2014;6: 721-731. 
[33] Cerutti R, Pirinen E, Lamperti C, Marchet S, Sauve AA, Li W, Leoni V, Schon EA, Dantzer F, Auwerx J, Viscomi C, Zeviani M. NAD(+)-dependent activation of Sirt1 corrects the phenotype in a mouse model of mitochondrial disease. Cell Metab 2014;19: 1042-1049.

[34] Felici R, Lapucci A, Cavone L, Pratesi S, Berlinguer-Palmini R, Chiarugi A. Pharmacological NAD-Boosting Strategies Improve Mitochondrial Homeostasis in Human Complex I-Mutant Fibroblasts. Mol Pharmacol 2015;87: 965-71.

[35] Johnson SC, Yanos ME, Kayser EB, Quintana A, Sangesland M, Castanza A, Uhde L, Hui J, Wall VZ, Gagnidze A, Oh K, Wasko BM, Ramos FJ, Palmiter RD, Rabinovitch PS, Morgan PG, Sedensky MM, Kaeberlein M. mTOR inhibition alleviates mitochondrial disease in a mouse model of Leigh syndrome. Science 2013;342: 1524-1528.

[36] Khan NA, Nikkanen J, Yatsuga S, Jackson C, Wang L, Pradhan S, Kivela R, Pessia A, Velagapudi V, Suomalainen A. mTORC1 Regulates Mitochondrial Integrated Stress Response and Mitochondrial Myopathy Progression. Cell Metab 2017;26: 419-428.e5.

[37] Siegmund SE, Yang H, Sharma R, Javors M, Skinner O, Mootha V, Hirano M, Schon EA. Low-dose rapamycin extends lifespan in a mouse model of mtDNA depletion syndrome. Hum Mol Genet 2017;26: 45884605.

[38] Barriocanal-Casado E, Hidalgo-Gutierrez A, Raimundo N, Gonzalez-Garcia P, Acuna-Castroviejo D, Escames G, Lopez LC. Rapamycin administration is not a valid therapeutic strategy for every case of mitochondrial disease. EBioMedicine 2019;42: 511-523.

[39] Johnson SC, Martinez F, Bitto A, Gonzalez B, Tazaerslan C, Cohen C, Delaval L, Timsit J, Knebelmann B, Terzi F, Mahal T, Zhu Y, Morgan PG, Sedensky MM, Kaeberlein M, Legendre C, Suh Y, Canaud G. mTOR inhibitors may benefit kidney transplant recipients with mitochondrial diseases. Kidney Int 2019;95: 455-466. [40] Sage-Schwaede A, Engelstad K, Salazar R, Curcio A, Khandji A, Garvin JH, Jr., De Vivo DC. Exploring mTOR inhibition as treatment for mitochondrial disease. Ann Clin Transl Neurol 2019.

[41] Bao XR, Ong SE, Goldberger O, Peng J, Sharma R, Thompson DA, Vafai SB, Cox AG, Marutani E, Ichinose F, Goessling W, Regev A, Carr SA, Clish CB, Mootha VK. Mitochondrial dysfunction remodels one-carbon metabolism in human cells. Elife 2016;5.

[42] Nikkanen J, Forsstrom S, Euro L, Paetau I, Kohnz RA, Wang L, Chilov D, Viinamaki J, Roivainen A, Marjamaki P, Liljenback H, Ahola S, Buzkova J, Terzioglu M, Khan NA, Pirnes-Karhu S, Paetau A, Lonnqvist T, Sajantila A, Isohanni P, Tyynismaa H, Nomura DK, Battersby BJ, Velagapudi V, Carroll CJ, Suomalainen A. Mitochondrial DNA Replication Defects Disturb Cellular dNTP Pools and Remodel One-Carbon Metabolism. Cell Metab 2016;23: 635-48.

[43] Jain IH, Zazzeron L, Goli R, Alexa K, Schatzman-Bone S, Dhillon H, Goldberger O, Peng J, Shalem O, Sanjana NE, Zhang F, Goessling W, Zapol WM, Mootha VK. Hypoxia as a therapy for mitochondrial disease. Science 2016;352: 54-61.

[44] Jain IH, Zazzeron L, Goldberger O, Marutani E, Wojtkiewicz GR, Ast T, Wang H, Schleifer G, Stepanova A, Brepoels K, Schoonjans L, Carmeliet P, Galkin A, Ichinose F, Zapol WM, Mootha VK. Leigh Syndrome Mouse Model Can Be Rescued by Interventions that Normalize Brain Hyperoxia, but Not HIF Activation. Cell Metab 2019.

[45] Mootha VK, Chinnery PF. Oxygen in mitochondrial disease: can there be too much of a good thing? J Inherit Metab Dis 2018;41: 761-763.

[46] Peters MJ, Jones GA, Eaton S, Wiley D, Ray S. Risks and benefits of oxygen therapy. J Inherit Metab Dis 2018;41: 757-759.

[47] Karaa A, Haas R, Goldstein A, Vockley J, Weaver WD, Cohen BH. Randomized dose-escalation trial of elamipretide in adults with primary mitochondrial myopathy. Neurology 2018;90: e1212-e1221.

[48] Reddy PH, Manczak M, Kandimalla R. Mitochondria-targeted small molecule SS31: a potential candidate for the treatment of Alzheimer's disease. Hum Mol Genet 2017;26: 1483-1496.

[49] Koenig MK, Emrick L, Karaa A, Korson M, Scaglia F, Parikh S, Goldstein A. Recommendations for the Management of Strokelike Episodes in Patients With Mitochondrial Encephalomyopathy, Lactic Acidosis, and Strokelike Episodes. JAMA Neurol 2016;73: 591-4. 
[50] Koga Y, Ishibashi M, Ueki I, Yatsuga S, Fukiyama R, Akita Y, Matsuishi T. Effects of L-arginine on the acute phase of strokes in three patients with MELAS. Neurology 2002;58: 827-828.

[51] Koga Y, Povalko N, Inoue E, Nakamura H, Ishii A, Suzuki Y, Yoneda M, Kanda F, Kubota M, Okada H, Fujii K. Therapeutic regimen of L-arginine for MELAS: 9-year, prospective, multicenter, clinical research. J Neurol 2018;265: 2861-2874.

[52] Lopez-Gomez C, Levy RJ, Sanchez-Quintero MJ, Juanola-Falgarona M, Barca E, Garcia-Diaz B, Tadesse S, Garone C, Hirano M. Deoxycytidine and Deoxythymidine Treatment for Thymidine Kinase 2 Deficiency. Ann Neurol 2017;81: 641-652.

[53] Dominguez-Gonzalez C, Madruga-Garrido M, Mavillard F, Garone C, Aguirre-Rodriguez FJ, Donati MA, Kleinsteuber K, Marti I, Martin-Hernandez E, Morealejo-Aycinena JP, Munell F, Nascimento A, Kalko SG, Sardina MD, Alvarez Del Vayo C, Serrano O, Long Y, Tu Y, Levin B, Thompson JLP, Engelstad K, Uddin J, TorresTorronteras J, Jimenez-Mallebrera C, Marti R, Paradas C, Hirano M. Deoxynucleoside Therapy for Thymidine Kinase 2-Deficient Myopathy. Ann Neurol 2019;86: 293-303.

[54] Torres-Torronteras J, Gomez A, Eixarch H, Palenzuela L, Pizzorno G, Hirano M, Andreu AL, Barquinero J, Marti R. Hematopoietic gene therapy restores thymidine phosphorylase activity in a cell culture and a murine model of MNGIE. Gene Ther. 2011;18: 795-806.

[55] Di Meo I, Auricchio A, Lamperti C, Burlina A, Viscomi C, Zeviani M. Effective AAV-mediated gene therapy in a mouse model of ethylmalonic encephalopathy. EMBO Mol.Med. 2012;4: 1008-1014.

[56] Bottani E, Giordano C, Civiletto G, Di Meo I, Auricchio A, Ciusani E, Marchet S, Lamperti C, d'Amati G, Viscomi C, Zeviani M. AAV-mediated liver-specific MPV17 expression restores mtDNA levels and prevents dietinduced liver failure. Mol Ther 2014;22: 10-7.

[57] Di Meo I, Marchet S, Lamperti C, Zeviani M, Viscomi C. AAV9-based gene therapy partially ameliorates the clinical phenotype of a mouse model of Leigh syndrome. Gene Ther 2017;24: 661-667.

[58] Romero-Moya D, Santos-Ocana C, Castano J, Garrabou G, Rodriguez-Gomez JA, Ruiz-Bonilla V, Bueno C, Gonzalez-Rodriguez P, Giorgetti A, Perdiguero E, Prieto C, Moren-Nunez C, Fernandez-Ayala DJ, Victoria Cascajo M, Velasco I, Canals JM, Montero R, Yubero D, Jou C, Lopez-Barneo J, Cardellach F, Munoz-Canoves P, Artuch R, Navas P, Menendez P. Genetic Rescue of Mitochondrial and Skeletal Muscle Impairment in an Induced Pluripotent Stem Cells Model of Coenzyme Q10 Deficiency. Stem Cells 2017;35: 1687-1703.

[59] Bacman SR, Williams SL, Pinto M, Peralta S, Moraes CT. Specific elimination of mutant mitochondrial genomes in patient-derived cells by mitoTALENs. Nat.Med. 2013;19: 1111-1113.

[60] Gammage PA, Rorbach J, Vincent AI, Rebar EJ, Minczuk M. Mitochondrially targeted ZFNs for selective degradation of pathogenic mitochondrial genomes bearing large-scale deletions or point mutations. EMBO Mol.Med. 2014;6: 458-466.

[61] Bacman SR, Kauppila JHK, Pereira CV, Nissanka N, Miranda M, Pinto M, Williams SL, Larsson NG, Stewart JB, Moraes CT. MitoTALEN reduces mutant mtDNA load and restores tRNA(Ala) levels in a mouse model of heteroplasmic mtDNA mutation. Nat Med 2018;24: 1696-1700.

[62] Gammage PA, Viscomi C, Simard ML, Costa ASH, Gaude E, Powell CA, Van Haute L, McCann BJ, RebeloGuiomar P, Cerutti R, Zhang L, Rebar EJ, Zeviani M, Frezza C, Stewart JB, Minczuk M. Genome editing in mitochondria corrects a pathogenic mtDNA mutation in vivo. Nat Med 2018;24: 1691-1695.

[63] Feuer WJ, Schiffman JC, Davis JL, Porciatti V, Gonzalez P, Koilkonda RD, Yuan H, Lalwani A, Lam BL, Guy J. Gene Therapy for Leber Hereditary Optic Neuropathy: Initial Results. Ophthalmology 2016;123: 558-70.

[64] Halter JP, Michael W, Schupbach M, Mandel H, Casali C, Orchard K, Collin M, Valcarcel D, Rovelli A, Filosto M, Dotti MT, Marotta G, Pintos G, Barba P, Accarino A, Ferra C, Illa I, Beguin Y, Bakker JA, Boelens JJ, de Coo IF, Fay K, Sue CM, Nachbaur D, Zoller H, Sobreira C, Pinto Simoes B, Hammans SR, Savage D, Marti R, Chinnery PF, Elhasid R, Gratwohl A, Hirano M. Allogeneic haematopoietic stem cell transplantation for mitochondrial neurogastrointestinal encephalomyopathy. Brain 2015;138: 2847-58.

[65] De Giorgio R, Pironi L, Rinaldi R, Boschetti E, Caporali L, Capristo M, Casali C, Cenacchi G, Contin M, D'Angelo R, D'Errico A, Gramegna LL, Lodi R, Maresca A, Mohamed S, Morelli MC, Papa V, Tonon C, Tugnoli V, Carelli V, D'Alessandro R, Pinna AD. Liver transplantation for mitochondrial neurogastrointestinal encephalomyopathy. Ann Neurol 2016;80: 448-55. 
[66] Dionisi-Vici C, Diodato D, Torre G, Picca S, Pariante R, Giuseppe Picardo S, Di Meo I, Rizzo C, Tiranti V, Zeviani M, De Ville De Goyet J. Liver transplant in ethylmalonic encephalopathy: a new treatment for an otherwise fatal disease. Brain 2016;139: 1045-51.

[67] Bax BE, Levene M, Bain MD, Fairbanks LD, Filosto M, Kalkan Ucar S, Klopstock T, Kornblum C, Mandel H, Rahman S, Roubertie A, Scarpelli M, Sedgwick PM, Baru M, Sellos-Moura M, Price J, Horn P, Nirmalananthan N. Erythrocyte Encapsulated Thymidine Phosphorylase for the Treatment of Patients with Mitochondrial Neurogastrointestinal Encephalomyopathy: Study Protocol for a Multi-Centre, Multiple Dose, Open Label Trial. J Clin Med 2019;8.

\section{Figure legend}

Figure 1: Emerging therapies for mitochondrial disease

Approaches to treat primary mitochondrial diseases that are currently in development include redox modulation using antioxidants, harnessing mitochondrial biogenesis, stabilising the mitochondrial membrane lipid cardiolipin with elamipretide, targeting mitophagy using rapamycin, nucleoside supplementation to bypass the molecular defect in thymidine kinase 2 deficiency, heteroplasmy shifting using MitoTALENs and zinc finger nucleases, and gene and cell therapies. 
Table 1: Selection of currently active interventional trials for primary mitochondrial disorders

\begin{tabular}{|c|c|c|c|c|c|c|c|c|c|}
\hline $\begin{array}{l}\text { Agent } \\
\text { (other names) }\end{array}$ & Trial number & $\begin{array}{l}\text { Mechanism of } \\
\text { action }\end{array}$ & Disorder & $\begin{array}{l}\text { Age } \\
\text { range }\end{array}$ & Design & \begin{tabular}{|l|} 
Primary \\
outcome \\
measures
\end{tabular} & Status & Sponsor & $\begin{array}{l}\text { Type of } \\
\text { study }\end{array}$ \\
\hline KL 1333 & NCT03888716 & $\begin{array}{l}\text { NAD+ modulator } \\
\text { (mitochondrial } \\
\text { biogenesis) }\end{array}$ & $\begin{array}{ll}\text { - } & \text { Mitochondrial } \\
& \text { diseases } \\
\text { - } & \text { Mitochondrial } \\
& \text { respiratory chain } \\
& \text { deficiencies } \\
\text { - } & \text { MELAS syndrome } \\
\text { - } & \text { Mitochondrial } \\
& \text { myopathies }\end{array}$ & $\begin{array}{l}18- \\
75 y\end{array}$ & $\begin{array}{l}\text { Phase } 1 a / 1 b \\
\text { Randomised, } \\
\text { placebo- } \\
\text { controlled }\end{array}$ & Safety & Recruiting & NeuroVive & Industry \\
\hline $\begin{array}{l}\text { Nicotinamide } \\
\text { riboside }\end{array}$ & NCT03432871 & $\begin{array}{l}\text { Increase NAD+ } \\
\text { (mitochondrial } \\
\text { biogenesis) }\end{array}$ & $\begin{array}{ll}\text { - } & \text { Mitochondrial } \\
& \text { diseases } \\
\text { - } & \text { Mitochondrial } \\
\text { myopathies } \\
\text { - } \\
\text { Progressive } \\
\text { external } \\
\text { ophthalmoplegia } \\
\text { - Mitochondrial } \\
\text { DNA deletion } \\
\text { - MELAS }\end{array}$ & $\begin{array}{l}18- \\
70 y\end{array}$ & $\begin{array}{l}\text { Phase } 1 \\
\text { Open label }\end{array}$ & $\begin{array}{l}\text { Bioavailability, } \\
\text { safety, } \\
\text { mitochondrial } \\
\text { biogenesis } \\
\text { (assessed by } \\
\text { muscle biopsy) }\end{array}$ & Recruiting & $\begin{array}{l}\text { Cambridge } \\
\text { University } \\
\text { Hospitals NHS } \\
\text { Foundation } \\
\text { Trust, UK }\end{array}$ & $\begin{array}{l}\text { Investigator } \\
\text { led }\end{array}$ \\
\hline REN001 & NCT03862846 & $\begin{array}{l}\text { PPAR } \delta \text { agonist } \\
\text { (mitochondrial } \\
\text { biogenesis) }\end{array}$ & $\begin{array}{ll}\text { - } & \text { Primary } \\
\text { mitochondrial } \\
\text { myopathy }\end{array}$ & $\geq 16 y$ & $\begin{array}{l}\text { Phase } 1 \\
\text { Open label }\end{array}$ & $\begin{array}{l}\text { Safety and } \\
\text { tolerability } \\
\text { (assessed by } \\
\text { number of } \\
\text { participants } \\
\text { with adverse } \\
\text { events) }\end{array}$ & Recruiting & $\begin{array}{l}\text { Reneo Pharma } \\
\text { Ltd }\end{array}$ & Industry \\
\hline Resveratrol & NCT03728777 & $\begin{array}{l}\text { Mitochondrial } \\
\text { biogenesis }\end{array}$ & $\begin{array}{l}\text { - } \begin{array}{l}\text { Mitochondrial } \\
\text { myopathies }\end{array} \\
\end{array}$ & $\begin{array}{l}18- \\
80 y\end{array}$ & $\begin{array}{l}\text { Double-blind, } \\
\text { randomized, } \\
\text { placebo- } \\
\text { controlled, }\end{array}$ & $\begin{array}{l}\text { Decrease in } \\
\text { heart rate } \\
\text { during } \\
\text { constant load }\end{array}$ & Recruiting & $\begin{array}{l}\text { Rigshospitalet, } \\
\text { Denmark }\end{array}$ & $\begin{array}{l}\text { Investigator } \\
\text { led }\end{array}$ \\
\hline
\end{tabular}




\begin{tabular}{|c|c|c|c|c|c|c|c|c|c|}
\hline & & & & & $\begin{array}{l}\text { cross-over } \\
\text { study }\end{array}$ & $\begin{array}{l}\text { cycling } \\
\text { exercise }\end{array}$ & & & \\
\hline $\begin{array}{l}\text { Sodium } \\
\text { phenylbutyrate }\end{array}$ & NCT03734263 & $\begin{array}{l}\text { Stabilisation of } \\
\text { PDHc enzyme }\end{array}$ & - PDHc deficiency & $\begin{array}{l}3 \mathrm{~m}- \\
18 \mathrm{y}\end{array}$ & $\begin{array}{l}\text { Phase } 1 / 2 \\
\text { Open label }\end{array}$ & $\begin{array}{l}\text { Blood lactate } \\
\text { level }\end{array}$ & Recruiting & $\begin{array}{l}\text { Fondazione } \\
\text { Telethon }\end{array}$ & $\begin{array}{l}\text { Investigator } \\
\text { led }\end{array}$ \\
\hline Dichloroacetate & NCT02616484 & $\begin{array}{l}\text { Decrease } \\
\text { inactivation of } \\
\text { PDHc by } \\
\text { inhibiting PDK }\end{array}$ & - PDHc deficiency & $\begin{array}{l}6 m- \\
17 y\end{array}$ & $\begin{array}{l}\text { Phase } 3 \\
\text { Randomised, } \\
\text { placebo- } \\
\text { controlled, } \\
\text { quadruple- } \\
\text { masked, } \\
\text { crossover } \\
\text { study }\end{array}$ & $\begin{array}{l}\text { Observer } \\
\text { reported } \\
\text { outcome } \\
\text { (ObsRO) } \\
\text { measure of } \\
\text { health }\end{array}$ & Recruiting & $\begin{array}{l}\text { University of } \\
\text { Florida, } \\
\text { Columbia } \\
\text { University, } \\
\text { Medosome } \\
\text { Biotec LLC, Saol } \\
\text { Therapeutics }\end{array}$ & $\begin{array}{l}\text { Investigator } \\
\text { led/ } \\
\text { Industry }\end{array}$ \\
\hline $\begin{array}{l}\text { ScAAV2- } \\
\text { P1ND4V2 }\end{array}$ & NCT02161380 & $\begin{array}{l}\text { Adeno- } \\
\text { associated virus } \\
\text { vector gene } \\
\text { therapy }\end{array}$ & - LHON & $\geq 15 y$ & $\begin{array}{l}\text { Phase } 1 \\
\text { Open-label } \\
\text { dose } \\
\text { escalation } \\
\text { study }\end{array}$ & Toxicity & Recruiting & $\begin{array}{l}\text { John Guy, } \\
\text { National Eye } \\
\text { Institute, } \\
\text { University of } \\
\text { Miami }\end{array}$ & $\begin{array}{l}\text { Investigator } \\
\text { led }\end{array}$ \\
\hline AHSCT & NCT02427178 & $\begin{array}{l}\text { Allogeneic } \\
\text { hematopoietic } \\
\text { stem cell } \\
\text { transplant }\end{array}$ & - MNGIE & $5-55 y$ & Phase 1 & $\begin{array}{l}\text { Engraftment } \\
\text { success } \\
\text { (neutrophil } \\
\text { count) }\end{array}$ & Recruiting & $\begin{array}{l}\text { Michio Hirano, } \\
\text { Cornell } \\
\text { University, } \\
\text { National } \\
\text { Institute of } \\
\text { Neurological } \\
\text { Disorders and } \\
\text { Stroke }\end{array}$ & $\begin{array}{l}\text { Investigator } \\
\text { led }\end{array}$ \\
\hline $\begin{array}{l}\text { MT1621 } \\
\text { (Combination } \\
\text { pyrimidine } \\
\text { nucleosides) }\end{array}$ & NCT03845712 & $\begin{array}{l}\text { Nucleoside } \\
\text { supplementation }\end{array}$ & - TK2 deficiency & $\begin{array}{l}\text { All } \\
\text { ages }\end{array}$ & $\begin{array}{l}\text { Phase } 2 \\
\text { Open label } \\
\text { extension }\end{array}$ & Safety & $\begin{array}{l}\text { Enrolling } \\
\text { by } \\
\text { invitation }\end{array}$ & $\begin{array}{l}\text { Modis } \\
\text { Therapeutics, } \\
\text { Inc. }\end{array}$ & Industry \\
\hline $\begin{array}{l}\text { Autologous } \\
\text { CD34+ } \\
\text { haematopoietic } \\
\text { stem cells }\end{array}$ & NCT03384420 & $\begin{array}{l}\text { 'Mitochondria } \\
\text { augmentation } \\
\text { therapy' }\end{array}$ & $\begin{array}{l}\text { - Pearson } \\
\text { syndrome }\end{array}$ & $\begin{array}{l}\text { All } \\
\text { ages }\end{array}$ & Phase $1 / 2$ & $\begin{array}{l}\text { Number of } \\
\text { participants } \\
\text { with } \\
\text { treatment- }\end{array}$ & $\begin{array}{l}\text { Enrolling } \\
\text { by } \\
\text { invitation }\end{array}$ & $\begin{array}{l}\text { Minovia } \\
\text { Therapeutics } \\
\text { Ltd. }\end{array}$ & Industry \\
\hline
\end{tabular}




\begin{tabular}{|c|c|c|c|c|c|c|c|c|c|}
\hline $\begin{array}{l}\text { enriched with } \\
\text { MNV-BLD }\end{array}$ & & & & & & $\begin{array}{l}\text { related } \\
\text { adverse events }\end{array}$ & & & \\
\hline $\begin{array}{l}\text { EPI-743 } \\
\text { (Vincerinone) }\end{array}$ & NCT02352896 & Antioxidant & - Leigh syndrome & $1-18 y$ & $\begin{array}{l}\text { Phase } 2 \\
\text { Open label }\end{array}$ & $\begin{array}{l}\text { Long term } \\
\text { effect on } \\
\text { disease } \\
\text { severity } \\
\text { (NPMDS) }\end{array}$ & $\begin{array}{l}\text { Active, } \\
\text { not } \\
\text { recruiting }\end{array}$ & $\begin{array}{l}\text { Edison } \\
\text { Pharmaceuticals } \\
\text { Inc. }\end{array}$ & Industry \\
\hline $\begin{array}{l}\text { EPI-743 } \\
\text { (Vincerinone) }\end{array}$ & NCT01370447 & Antioxidant & $\begin{array}{l}\text { - Mitochondrial } \\
\text { diseases }\end{array}$ & $\geq 1 y$ & $\begin{array}{l}\text { Phase } 2 \\
\text { Open label }\end{array}$ & $\begin{array}{l}\text { Change in } \\
\text { neuromuscular } \\
\text { function, } \\
\text { adverse } \\
\text { events, } \\
\text { NPMDS score }\end{array}$ & $\begin{array}{l}\text { Active, } \\
\text { not } \\
\text { recruiting }\end{array}$ & $\begin{array}{l}\text { Edison } \\
\text { Pharmaceuticals } \\
\text { Inc. }\end{array}$ & Industry \\
\hline $\begin{array}{l}\text { EPI-743 } \\
\text { (Vincerinone) }\end{array}$ & NCT01642056 & Antioxidant & $\begin{array}{l}\text { - Mitochondrial } \\
\text { disease }\end{array}$ & $2-11 y$ & $\begin{array}{l}\text { Phase } 1 / 2 \\
\text { Non- } \\
\text { randomised, } \\
\text { double-blind, } \\
\text { placebo- } \\
\text { controlled } \\
\text { crossover }\end{array}$ & NPMDS score & $\begin{array}{l}\text { Active, } \\
\text { not } \\
\text { recruiting }\end{array}$ & $\begin{array}{l}\text { National Human } \\
\text { Genome } \\
\text { Research } \\
\text { Institute }\end{array}$ & $\begin{array}{l}\text { Investigator } \\
\text { led }\end{array}$ \\
\hline $\begin{array}{l}\text { NAB-Sirolimus } \\
\text { (ABI-009) }\end{array}$ & NCT03747328 & $\begin{array}{l}\text { Targeting } \\
\text { mitophagy }\end{array}$ & $\begin{array}{l}\text { - Leigh syndrome } \\
\text { (genetically } \\
\text { confirmed) }\end{array}$ & $2-17 y$ & $\begin{array}{l}\text { Phase 2A } \\
\text { Open label }\end{array}$ & $\begin{array}{l}\text { Number of } \\
\text { participants } \\
\text { with adverse } \\
\text { events, GMFM }\end{array}$ & $\begin{array}{l}\text { Active, } \\
\text { not yet } \\
\text { recruiting }\end{array}$ & Aadi, LLC & Industry \\
\hline $\begin{array}{l}\text { Elamipretide } \\
\text { (MTP-131) }\end{array}$ & NCT03323749 & $\begin{array}{l}\text { Stabilisation of } \\
\text { cardiolipin }\end{array}$ & $\begin{array}{l}\text { - Primary } \\
\text { mitochondrial } \\
\text { myopathy }\end{array}$ & $\begin{array}{l}16- \\
80 y\end{array}$ & $\begin{array}{l}\text { Phase } 3 \\
\text { Randomized, } \\
\text { double-blind, } \\
\text { parallel-group, } \\
\text { placebo- } \\
\text { controlled }\end{array}$ & $\begin{array}{l}\text { 6MWT, } \\
\text { PMMSA } \\
\text { fatigue score }\end{array}$ & $\begin{array}{l}\text { Active, } \\
\text { not yet } \\
\text { recruiting }\end{array}$ & $\begin{array}{l}\text { Stealth } \\
\text { BioTherapeutics } \\
\text { Inc. }\end{array}$ & Industry \\
\hline L-citrulline & NCT03952234 & $\begin{array}{l}\text { Nitric oxide } \\
\text { precursor }\end{array}$ & - MELAS & $\begin{array}{l}18- \\
65 y\end{array}$ & $\begin{array}{l}\text { Phase } 1 \\
\text { Dose-finding }\end{array}$ & $\begin{array}{l}\text { Incidence of } \\
\text { dose limiting } \\
\text { toxicities, to } \\
\text { establish }\end{array}$ & $\begin{array}{l}\text { Active, } \\
\text { not yet } \\
\text { recruiting }\end{array}$ & $\begin{array}{l}\text { Baylor College } \\
\text { of Medicine, } \\
\text { National } \\
\text { Institutes of }\end{array}$ & $\begin{array}{l}\text { Investigator } \\
\text { led }\end{array}$ \\
\hline
\end{tabular}




\begin{tabular}{|l|l|l|l|l|l|l|l|l|}
\hline & & & & & $\begin{array}{l}\text { maximum } \\
\text { tolerable dose }\end{array}$ & $\begin{array}{l}\text { Health (NIH), } \\
\text { University of } \\
\text { South Florida, } \\
\text { Columbia } \\
\text { University }\end{array}$ \\
\hline $\begin{array}{l}\text { Erythrocyte } \\
\text { encapsulated } \\
\text { thymidine } \\
\begin{array}{l}\text { phosphorylase } \\
\text { (EE-TP) }\end{array}\end{array}$ & NCT03866954 & $\begin{array}{l}\text { Enzyme } \\
\text { replacement }\end{array}$ & $\bullet$ MNGIE & $\geq 12 y$ & $\begin{array}{l}\text { Phase 2 } \\
\text { Open label } \\
\text { (sequential } \\
\text { assignment) }\end{array}$ & Safety & $\begin{array}{l}\text { Active, } \\
\text { not yet } \\
\text { recruiting }\end{array}$ & $\begin{array}{l}\text { St George's, } \\
\text { University of } \\
\text { London, The } \\
\text { Clinical Trial } \\
\text { Company, } \\
\text { Orphan } \\
\text { Technologies } \\
\text { Ltd }\end{array}$ \\
\hline
\end{tabular}

Key: 6MWT six minute walk test, AHSCT allogeneic hematopoietic stem cell transplant, GMFM gross motor function measure, m months, LHON Leber hereditary optic neuropathy, MELAS mitochondrial encephalomyopathy with lactic acidosis and stroke-like episodes, MNGIE mitochondrial neurogastrointestinal encephalomyopathy, NPMDS Newcastle paediatric mitochondrial disease scale, PDHc pyruvate dehydrogenase complex, PDK pyruvate dehydrogenase kinase, PMMSA Primary Mitochondrial Disease Symptom Assessment, TK2 thymidine kinase 2, y years 


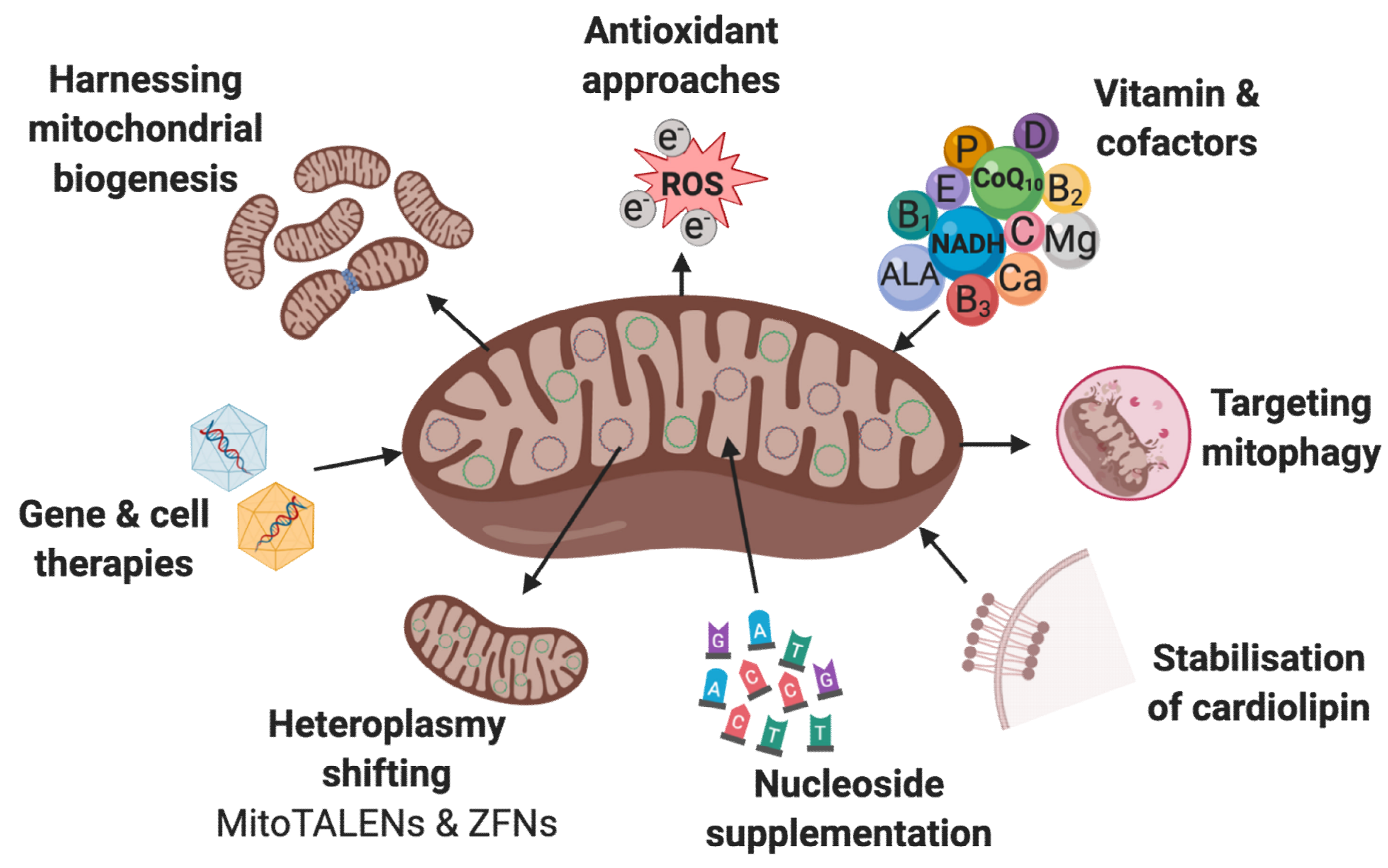

